\title{
Retraction Note to: A limit analysis of Mindlin plates using the cell-based smoothed triangular element CS-MIN3 and second-order cone programming (SOCP)
}

Nguyen-Thoi Trung ${ }^{1,2^{*}}$, Phung-Van Phuc ${ }^{1}$ and Le-Van Canh ${ }^{3}$

\section{${ }^{*}$ Correspondence:}

nguyenthoitrung@tdt.edu.vn

1 Division of Computational

Mathematics

and Engineering (CME),

Institute for Computational

Science (INCOS), Ton Duc

Thang University, Hochiminh

City, Viet Nam

Full list of author information

is available at the end of the article

\section{Retraction to: Asia Pacific Journal on Computational Engineering 2014, 1:6 DOI 10.1186/2196-1166-1-6}

This article [1] has been retracted by Professor Nguyen-Dang Hung, Editor-in-Chief of Asia Pacific Journal on Computational Engineering.

Upon investigation carried out according to the Committee on Publication Ethics guidelines, it has been found that the authors have duplicated substantial parts from the following article by T. Nguyen-Thoi, P. Phung-Van, M.H. Nguyen-Thoi, H. Dang-Trung [2], published in Journal of Computational Applied Mathematics.

This is a violation of publication ethics which, in accordance with the Springer Policy on Publishing Integrity, warrants a retraction of the article and a notice to this effect to be published in the journal.

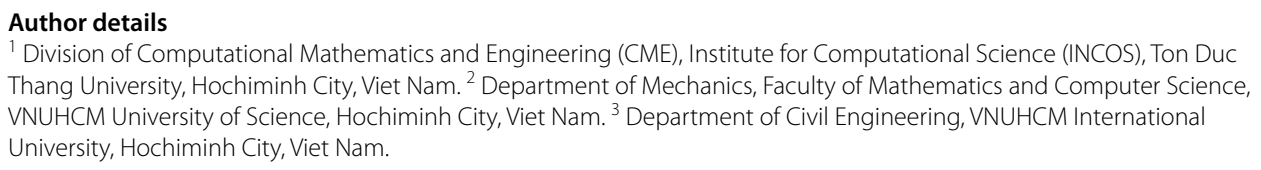
Thang University, Hochiminh City, Viet Nam. ${ }^{2}$ Department of Mechanics, Faculty of Mathematics and Computer Science, VNUHCM University of Science, Hochiminh City, Viet Nam. ${ }^{3}$ Department of Civil Engineering, VNUHCM International University, Hochiminh City, Viet Nam.

The online version of the original article can be found under doi:10.1186/2196-1166-1-6.

Received: 21 July 2015 Accepted: 21 July 2015

Published online: 21 August 2015

\footnotetext{
References

1. Trung NT, Phuc PV, Canh LV (2014) A limit analysis of Mindlin plates using the cell-based smoothed triangular element CS-MIN3 and second-order cone programming (SOCP). Asia Pac J Comput Eng 1:6. doi:10.1186/2196-1166-1-6 2. Nguyen-Thoi T, Phung-Van P, Nguyen-Thoi MH, Dang-Trung H (2015) An upper-bound limit analysis of Mindlin plates using CS-DSG3 method and second-order cone programming. J Comput Appl Math 281:32-48. doi:10.1016/j. cam.2014.12.006
}

\section{Springer}

(0) 2015 Trung et al. This article is distributed under the terms of the Creative Commons Attribution 4.0 International License (http:// creativecommons.org/licenses/by/4.0/), which permits unrestricted use, distribution, and reproduction in any medium, provided you give appropriate credit to the original author(s) and the source, provide a link to the Creative Commons license, and indicate if changes were made. The Creative Commons Public Domain Dedication waiver (http://creativecommons.org/publicdomain/ zero/1.0/) applies to the data made available in this article, unless otherwise stated. 